Lafayette in the Age of the American Revolution 


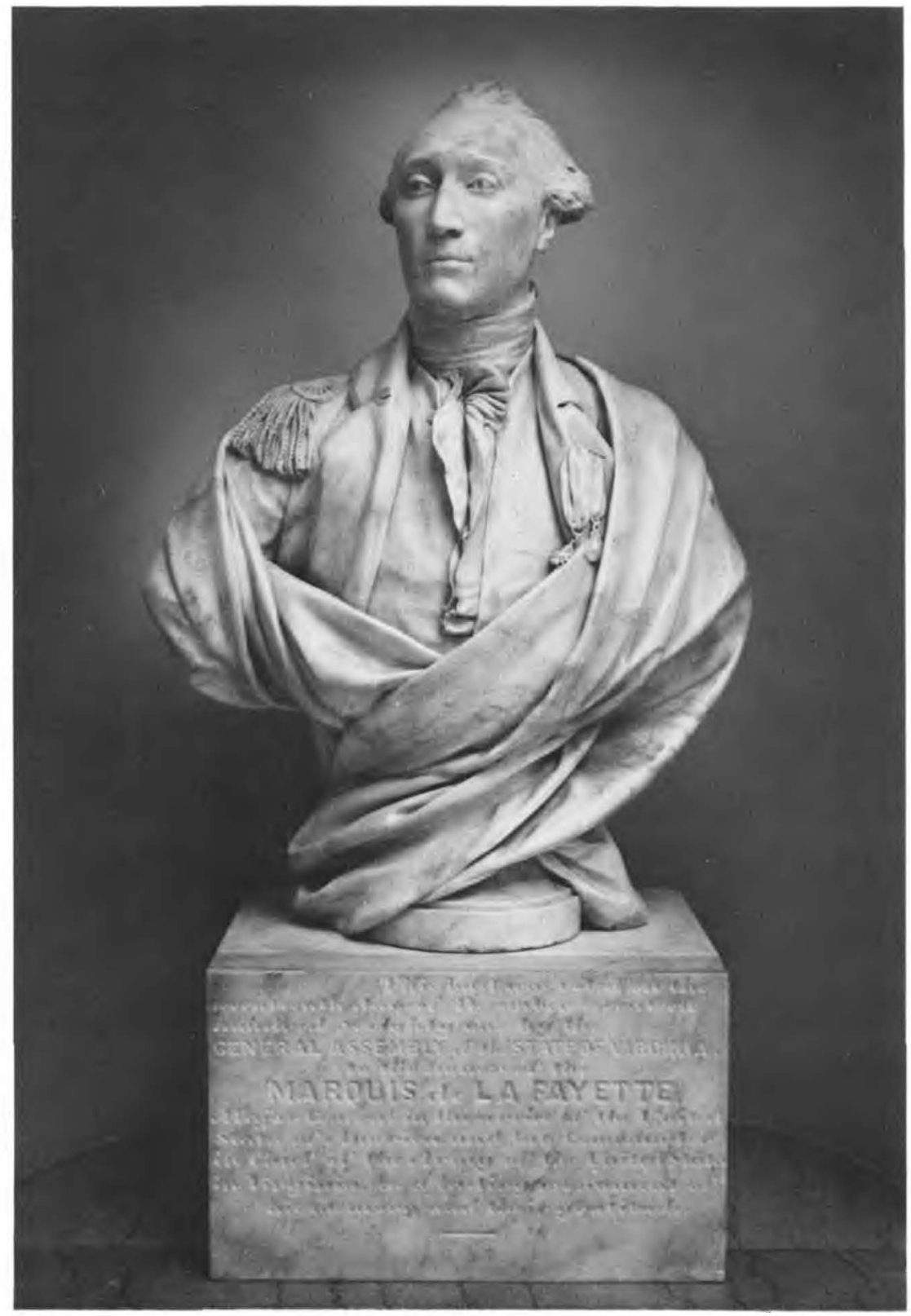

Bust of Lafayette by Jean-Antoine Houdon, now on display in the rotunda of the capitol at Richmond, Virginia, where it faces Houdon's statue of Washington. 


\title{
Lafayette in the Age of the American Revolution
}

SELECTED LETTERS AND PAPERS, $177^{6-1790}$

Volume V • January 4, 1782-December 29, 1785

\author{
STANLEY J. IDZERDA and \\ ROBERT RHODES CROUT, Editors
}

Carol Godschall and Leslie Wharton, Assistant Editors

CORNELL UNIVERSITY PRESS

ITHACA AND LONDON 
This book has been published with the aid of a grant from the National Historical Publications and Records Commission.

$$
\text { Copyright }(\mathcal{C} 1983 \text { by Cornell University }
$$

All rights reserved. Except for brief quotations in a review, this book, or parts thereof, must not be reproduced in any form without permission in writing from the publisher. For information address Cornell University Press, 124

Roberts Place, Ithaca, New York $14^{8} 5^{\circ}$.

First published 1983 by Cornell University Press.

Published in the United Kingdom by Cornell University Press Lid., Ely House, 37 Dover Street, London $\mathrm{W}_{1} \mathrm{X}_{4} \mathrm{HQ}$.

International Standard Book Number o-8014-1576-4

Library of Congress Catalog Card Number $76-50268$

Printed in the United States of America

Librarians: Library of Congress cataloging information appears on the last page of the book.

The paper in this book is acid-free, and meets the guidelines for permanence and durability of the Committee on Production Guidelines for Book Longevity of the Council on Library Resources. 
THE PAPERS OF THE MARQUIS DE LAFAYETTE

Sponsored by the Cornell University Libraries, the National Historical Publications and Records Commission, and the National Endowment for the Humanities ADVISORY BOARD

E. Marie Benabou, Université de Paris I Yves-Marie Bercé, Université de Limoges

Louis Bergeron, Ecole des Hautes Etudes en Sciences Sociales Herbert Dieckmann, Cornell University

Durand Echeverria, Brown University

C. Herbert Finch, Cornell University

Jacques Godechot, Université de Toulouse Michael G. Kammen, Cornell University

J. Gormly Miller, Cornell University

Mary Beth Norton, Cornell University

Steven L. Kaplan, Cornell University

Robert R. Palmer, Yale University

George W. Pierson, Yale University

Howard C. Rice, Jr., Princeton University

Fred Somkin, Cornell University

Chantal de Tourtier-Bonazzi, Archives Nationales

HONORARY MEMBERS

Arthur H. Dean

Comte René de Chambrun

Mary Marden Dean 
